\title{
INFLUENCE OF INTERNATIONAL ECONOMIC INTEGRATION ON SOCIO-ECONOMIC DEVELOPMENT OF REGION
}

The hypothesis about new type's integration processes in the world economy is made, the essence and distinctive peculiarities of these processes are determined. By the proposed groups of parameters, the comparative analysis of international economic integration (IEI) within traditional integration processes (EU, NAFTA) and those of new type (SCO, BRIC(S)) is carried out. The technique of estimation of influence of international economic integration on development of a country's region is worked out, and the estimation of influence of international economic integration on socio-economic development of Sverdlovsk region is carried out.

The movement of goods, services and factors of production (capital, work force) between the region and the integration associations of traditional type and the groups of countries arisen in terms of forming integration processes of new type is analyzed. It is shown that the one of the tendencies in development of international economic integration of Sverdlovsk region during the last 12 years has been the increasing role and importance of new integration groups of countries. It is revealed that the purposeful account of this tendency can provide quantitative and qualitative shifts in external trade, foreign investments and labor migration of the region, related on the change of direction of flows: from the receivers of high-technological goods, capital, specialists from developed countries - to the supplier of manufactured goods, investments and high-qualified work force into countries of SCO and BIRC(S), what is one of the factors of providing economic safety of the region.

Keywords: international economic integration, EU, NAFTA, SCO, BRIC(S), international trade, foreign investments, migration, region, social-economic development

In conditions of strengthening global economic cooperation, almost all regions of the world are covered with the process of international economic integration (IEI). International economic

\footnotetext{
${ }^{1}$ (c) Andreyeva Ye. L., Zakharova V. V., Ratner A. V. Text. 2014.
}

integration is a complex process of coaptation and diffusion of national economies of various countries, aiming to create a unified economic organism. European Union (EU) is an example of the most developed international economic integration association. The emerging crises in EU deny 
the uniqueness of the classic international economic integration model and lead to a rethinking of the laws of its development. Modern investigation of integration success of EU with use of such criteria as presence of a single market, homogeneity, symmetry and conformity, shows "the EU countries form a heterogeneous community rather than a homogeneous group of countries with similar integration levels" [8, p. 1083]. During the growing difficulties in EU and NAFTA the significance of the Shanghai Cooperation Organization (SCO) and BRIC(S) is increasing, as these organizations are formed by the largest emerging economies of the world, including Russia. Therefore, the study of new forms of integration processes seems an interesting field both in the context of its impact on the Russian economy in general and on the social and economic situations in certain regions of Russia.

\section{Forming the integration processes of a new type as the most important trend in the world economy}

The world economy in the twenty-first century can be characterized by fundamental changes connected with the global redistribution of power and influence, the loss of the world's leading economic centers their stable positions, acquisition of "atypical for certain peripheral countries economic power and geopolitical importance.” These countries are on a rising wave of the economic cycle and thus have an advantage over developed countries. At the same time the largest emerging economies of the world have the following factors of further economic growth, which can be performed as advantages over developed countries:

- high resource endowment and great potential of economic development. Thus, EU and NAFTA have $7.1 \%$ and $6.5 \%$ of the world of "human resources" respectively, SCO and BRIC(S) $21.0 \%$ and $41.8 \%$. EU and NAFTA have $2.3 \%$ and $4.9 \%$ world gas reserves, and SCO and BRIC(S) $26.9 \%$ and $25.8 \%$. The shares of NAFTA and EU in global reserves of iron ore are 2.8 and $6 \%$, and the shares of SCO and BRIC(S) - 27.8 and $52.9 \%$ [20].

- the largest developing countries in the world, with producing GDP and getting GNI, send a considerable part of it on the accumulation, thereby laying it in the development. Such economic development strategy is called the Asian systematic accumulation cycle.

Institutionalization of the common interests of SCO and BRIC(S) has become a response to attempts of preserving the economic hegemony of the United States in the conditions when the old mechanisms of global regulation created by the U.S. as the Bretton Woods system (IMF and World Bank) are not working. The global financial and economic crisis has shown that the formation of a new world order and global architecture of the world economic regulation is required (including participation of developing countries, e.g. in the form of G20). According to L. Fituni and I. Abramova, "numerous researchers of global processes that belong to different schools, ... agree that the ongoing processes represent the change of epochs" [4, p. three].

This change of epochs has impacted on the formation of integration processes of a new type, when the institutionalization of common interests of the largest fast-developing countries - Brazil, Russia, India, China, South Africa, etc. - leads to the appearance of the integration organizations as SCO and BRIC(S). "For some year's reforms and greater openness have increased the global economic significance of the BRICs countries. These countries still have strong growth potential, especially in view of their large, young populations" [2, p. 20]. And now the "intra-BRICS cooperation... is defined by ample, increasingly technical cooperation between a growing number of ministries such as education, science and technology, agriculture, finance, and health" [16, p. 625]. A distinctive feature of the integration processes taking place within SCO and BRIC(S) is the fact that they do not match traditional economic integration plan, i.e., traditional presuppositions and arrangement of integration blocs. BRIC(S) countries are not closely connected geographically; moreover, there are no historical economic ties. Partners do not have similar languages (as the United States and Canada in NAFTA) or culture (as countries in EU). BRIC(S)-countries have different political and economic systems - from pluralism and market economy to the communist one-party and centralized government. The geography of geopolitical interests also differs CIS, Asia and the Pacific, Western Hemisphere.

We propose two groups of parameters for the classification of economic integration processes. The first one identifies the existence and properties of institutional integration design in the union (group of countries). We take in account the components like time of appearance, targets, integration mechanisms, and tools, the presence of formalized organizational structure, decision-making mechanisms, criteria for new countries inclusion. In the case of integration processes within the traditional integration organizations with a long history and successive stages of its development, the design process is more formalized (there are constituent instruments and 
Table 1

Comparative analysis of the processes of international economic integration

\begin{tabular}{|c|c|c|}
\hline \multirow{2}{*}{ Parameters } & \multicolumn{2}{|c|}{ Integration processes } \\
\hline & Within the established associations & Of the new type \\
\hline \multicolumn{3}{|c|}{ 1. Parameters of institutionalization of economic integration } \\
\hline Time of appearance & The $1940 \mathrm{~s}-1950 \mathrm{~s}$ & The $2000 \mathrm{~s}$ \\
\hline Purposes & $\begin{array}{c}\text { Interweaving of national reproduction } \\
\text { processes }\end{array}$ & $\begin{array}{l}\text { Overcoming the mismatch between the } \\
\text { role of countries in the world economy } \\
\text { and their economic potential }\end{array}$ \\
\hline Mechanisms and tools of integration & $\begin{array}{l}\text { Evolution of mechanisms within the } \\
\text { forms: Preferential Trade Area, Free- } \\
\text { Trade Area, Custom Union, Common } \\
\text { Market, Economic Union, Economic } \\
\text { And Monetary Union }\end{array}$ & $\begin{array}{l}\text { Multi-field integration agreements } \\
\text { (cooperation programs) }\end{array}$ \\
\hline Constitutive acts & Yes & Optional \\
\hline $\begin{array}{l}\text { Supporting organizational structure } \\
\text { (secretariat, etc.) }\end{array}$ & Yes & The presence of all elements is optional \\
\hline Supranational authorities & Yes & Optional \\
\hline $\begin{array}{l}\text { The right to make legally binding } \\
\text { decisions }\end{array}$ & Yes & No \\
\hline The participants & Limited & Floating \\
\hline Criteria for inclusion new members & Numerically defined & No clear determination \\
\hline Structure & Formed & In the stage of forming \\
\hline \multicolumn{3}{|c|}{ 2. Parameters of participating countries of economic integration } \\
\hline Economic development level & $\begin{array}{l}\text { Developed countries (income upper } \\
\text { middle) }\end{array}$ & $\begin{array}{l}\text { Developing countries (income average } \\
\text { and lower middle) }\end{array}$ \\
\hline $\begin{array}{l}\text { Dynamics of economic development } \\
\text { in the medium retrospect }\end{array}$ & Dynamics of stagnating or absent & Growth \\
\hline $\begin{array}{l}\text { Allocation of levels of economic } \\
\text { development of participating countries }\end{array}$ & Roughly the same & Different \\
\hline $\begin{array}{l}\text { Economic systems of participating } \\
\text { countries }\end{array}$ & Market & $\begin{array}{c}\text { Transitional (market and planning } \\
\text { items) }\end{array}$ \\
\hline $\begin{array}{l}\text { Commonality of social and economic } \\
\text { problems of participating countries }\end{array}$ & Presented & May be presented or not \\
\hline $\begin{array}{l}\text { The presence of an initiating center, } \\
\text { rallying countries }\end{array}$ & Yes & Controversial \\
\hline Geographical location & Close, compact & Both closely and not \\
\hline Historical economic ties & Presented & May be presented or not \\
\hline
\end{tabular}

good organizational structure). There is the right to take the legally binding decisions, and there are strict criteria for accepting new members. Thus in the case of traditional integration processes institutionalization expressed strongly, and that leads to integration organizations formation. Evolution of integration organizations was gradual with several stages. Integration processes within the new groups of countries are characterized by weak institutional design, their evolution passes through another scenario. Targets of an integration process within the framework of the SCO and BRIC(S) can be characterized as aspiration to overcome the contradictions between high potentials (demographic, resource, ideological, etc.) and inappropriate role of countries in the modern global economy.
The second group of parameters characterizes certain countries - organization members (groups of countries). We compare economic, territorial, resource capacities of countries and the role of these countries in the world. We correlate economic development levels and market systems of the participating countries, the dynamics of economic development, types of economic systems and character of the social and economic problems facing the country. We identify some historical economic connection between countries and a presence in the organization the initiating nucleus.

Table 1 below shows the comparative analysis of the processes of international economic integration in the framework of traditional integration associations and associations of the new type. 
The comparative analysis allowed us to give the following definition.

The integration processes of a new type processes of international economic integration emerged at the turn of XX-XXI centuries in terms of gradual evolution of the economic world order, which differ from international economic integration within the traditional integration organizations (EU, NAFTA, etc.) on the parameters of economic development of participating countries, as well as targets, mechanisms, and tools of integration.

Clearly, such processes will be successful, and their effectiveness will be enhanced, so in the future a new type of integration organizations can form. Countries-participants in the processes have an essential potential, although the view that the development of their relationship will move in the right direction is only a prediction.

\section{The methodology of estimation of the influence of international economic integration on regional development within the country}

Increasing importance of the international economic integration processes at the level of certain regions requires the formation of methodology of evaluation the impact of international economic integration on social and economic development of the region. Rising participation of regions of countries at external economic activity is caused by creating in certain regions of countries - of zones of high technologies, zones of economic and technological development having tax, customs and visa regimes [17].

The analysis of existing methodologies of evaluation the impact of international economic integration on social and economic development of the region of the country shows the following conclusions:

- existing methodologies evaluate the impact of international economic integration on the economy mostly at the national level, not at the level of a region;

- during the evaluation process the most-important trends of international economic integration are not considered;

- insufficient attention is paid on the analysis of the institutional component of the region's international economic integration ties

- no direct linkage with the indicators of socio-economic development of a particular region.

Figure 1 shows the proposed the methodology of estimation the influence of international economic integration on social and economic development of the region in four stages:
The first stage - estimation of the influence of the institutional component of region's integration relations on its social and economic development - includes:

a) estimation of influence of region's international integration cooperation agreements with certain integration association or group of countries on regional development. It consists in the analysis of kinds and spheres of cooperation within the international economic integration;

b) estimation of the indirect effect from measures being carried out in a region involving countries from the selected integration association. We have considered the typical positive phenomenon, reflecting the indirect effect. We have found that this often delayed effect can be expressed in sharing experiences in different fields of activities, investing in the development of region's infrastructure, providing impulse for further development of the hotel industry and the tourism industry in the region and exports its products due to additional advertising. The above measures contribute to economic recovery, job creation, growth of gross regional product.

The second stage - estimation of the influence of an international movement of goods and factors of production (IMGFP) on social and economic development of a region - includes:

a) quantitative analysis of an international movement of goods and factors of production (IMGFP) in the region with countries of specific integration associations or groups of countries includes a comparative assessment of the parameters of foreign trade; analysis of services turnover with these countries in the region, capital inflows from these countries and international flows of labor migrants.

In terms of external trade analysis we offer to assess, in particular, the regional import needs in significant products that affect the economic safety of the region.

b) analysis of correlation between indexes of IMGFP and regional social and economic development which includes the calculation of correlation coefficients between these indicators and the identification of interactions.

The third stage - revealing of indexes of IEI influence on social and economic development of a region - presupposes the consolidated assessment of essential positive or negative impact of IEI on the achievement of targets indexes in regional social and economic development. Peer review can be used additionally. We took the targets indexes from regional policy documents. Obtained results can be further used in SWOT-analyze. 
Estimation of influence of international economic integration (IEI) on social and economic development of region of a country

$1^{\text {st }}$ stage

Estimation of the influence of institutional component

of region's integration relations on its social and economic development

1.1. Estimation of influence of region's international integration cooperation agreements on regional development (by spheres of agreements activity)

1.2. Estimation of indirect postponed effect from measures being carried out in a region (related to integration cooperation) - for development of different kinds of infrastructure and promotion of local products

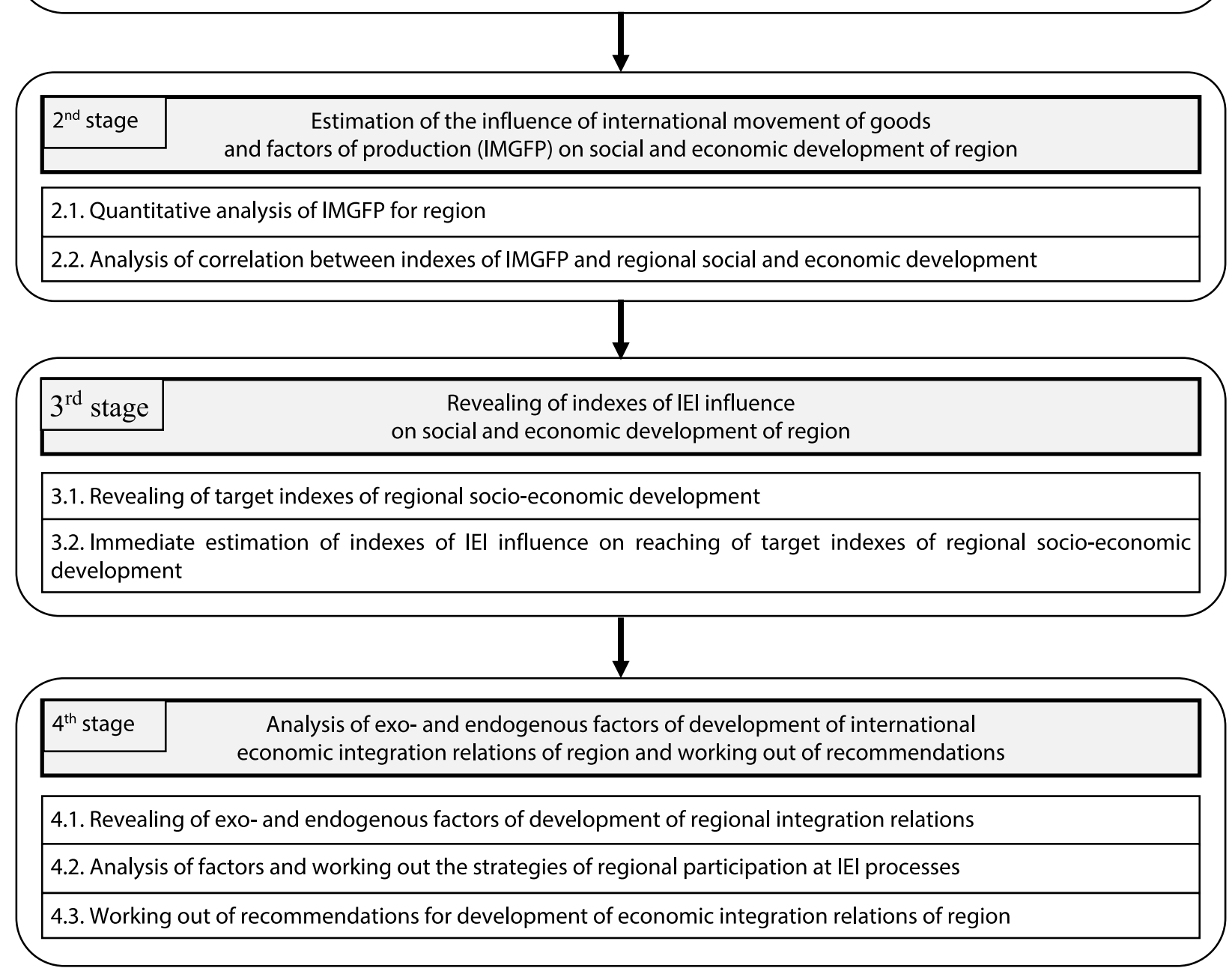

Fig. 1. Stages of estimation of IEl influence on social and economic development of country's region

Finally, during the fourth phase of estimation - analysis of exo- and endogenous factors of development of region's IEI relations - we identify opportunities and threats, strengths and weaknesses of the region in the context of IEI impact on social and economic development.

This allows us to offer recommendations on the developing strategies for region's participation in the process of IEI and to develop complex of actions for the implementation of these strategies.
Estimation of influence of international economic integration on social and economic development of Sverdlovsk region in the conditions of forming of a new type integration processes

The author's approach and given methodology were approved in Sverdlovsk region.

Firstly, the estimation of the influence of the institutional component of region's integration relations on its social and economic development was carried out. The analysis of existing agree- 
ments with countries-participators of SCO and BRIC(S) was done. We have identified which government agencies have signed the agreements and what is the duration of their action. We have found out that agreements include a wide range of forms of cooperation (economy and trade, industrial, technical and scientific cooperation, management, education, health, culture, etc.). "Economics and trade" involves such sectors as trade, cooperation, foreign investment, exchange of economic information, exchange of experience in various fields. We also found out that the agreements provide numerous tools of institutionalize (establishment of cooperation, formation of joint committees, opening of representative offices, regional information centers, etc.). Each form has a significant impact on the social and economic development of the region. For example, transport infrastructure, congress activities, hotel infrastructure, tourist complex in Yekaterinburg have received additional development because of the organization in Sverdlovsk region SCO Government meeting (15.06.2009) and the BRIC summit (16.06.2009). The effect of a realization such events has complex and long-term character.

Secondly, the estimation of the influence of an international movement of goods and factors of production (IMGFP) on social and economic development of Sverdlovsk region has been done.

1. Analysis of foreign trade of the Sverdlovsk region with different groups of countries. The gross foreign trade turnover of Sverdlovsk region in 2012 has increased in comparison with 2000 by four times. Approximately the same increase was observed with the EU countries. The growth was significantly lower with NAFTA -2.8 times, while the growth of region's turnover with SCO was 3.7 times. The highest growth rate was observed with BRIC(S) -6 times. At the same time, there is a decline in the share of the EU: from $44.7 \%$ in 2006 to $35.2 \%$ in 2012 . SCO share was growing: from $16.7 \%$ in 2000 to $26.0 \%$ in 2010. Almost tripled the share of the BRIC(S): from $5.5 \%$ in 2000 to $15.0 \%$ in 2010 [calculated on: 3].

Thus, we can speak about the tendency of conservation and even the raise of significance of region's foreign trade with such integration organizations as SCO and BRIC(S).

Characteristic of foreign trade of Sverdlovsk region for separate product groups assumes allocation of two main commodity groups:

1) raw commodities and products with low added value;

2) finished goods with high added value.

Such division seems relevant because the topic of the innovation economy is currently paid great attention [six]. Exports of Sverdlovsk region in EU and NAFTA is characterized by a low degree of processing (table 2). Thus, in the export structure of ferroalloys total share of EU and NAFTA is $66.7 \%$ (Kazakhstan was not taken into account in these statistics, due to the functioning of the Customs Union). Situation with a number of other exports items in the region (mostly related to metallurgy) is similar.

Import of the region, by contrast, is represented mostly by finished goods with high added value. In this structure, the share of traditional integration organizations - EU and NAFTA - formed by developed countries, exceeds $40 \%$ for a number of items. This concerns such commodity items as agricultural machinery, machine tools, bearings, motors, tractors, etc.

However, the certain part of Sverdlovsk region's export is represented by the goods of deep processing. The preponderance in the structure of such export is kept by the country groups in which the integration processes of a new type are passing, - SCO and BRIC(S): for example, the share of these countries in the structure of tires export is $73,0 \%$, in the structure of batteries export $79,0 \%$, in the structure of light vehicles and other motor transport - $100 \%$, etc.

As for import, Sverdlovsk region imports from these countries mainly food-stuffs, clothes and machinery, - that is, not only the products of high processing (as in the way with developed countries). At that it is to mark that the import of food-stuffs from post-socialistic countries being included at the moment into SCO, can advantageously differ for qualitative parameters from food import from developed countries being included into EU and NAFTA because of applying by them of genetically modified technologies, which influence isn't fully investigated, what can be in its turn a factor of risk for a number of illnesses including oncologic. The attention is given to these factors isn't sufficient. And at the same time, as the researchers of the Institute of economics of Ural branch of Russian academy of sciences have calculated [9, p. 260-263], a damage for gross regional product from these illnesses amounts in Sverdlovsk region to $0,93 \%$, or to 2,2 years of shortening of life duration by men. At that, it is one of the highest values among Russian regions. By taking into account our long-term experience of cooperation on the post-soviet space, common language, presence of the legislative framework worked out earlier, the upholding of own interests as well as of interests common with certain SCO countries seems to be realer than the incorporating into the standards of EU and NAFTA carry- 
Table 2

Structure of external trade of Sverdlovsk region by certain commodity positions, 2012 [calculated on: 3]

\begin{tabular}{|c|c|c|}
\hline \multirow[t]{2}{*}{ Commodity position } & \multicolumn{2}{|c|}{$\begin{array}{c}\text { Share of country groups at the } \\
\text { structure of external trade }\end{array}$} \\
\hline & $\mathrm{SCO}^{\star}$ and BRIC(S) & EU and NAFTA \\
\hline \multicolumn{3}{|l|}{ 1. Export } \\
\hline \multicolumn{3}{|c|}{ 1.1. Raw commodities and products with low added value } \\
\hline Ferro-alloys & 3,6 & 66,7 \\
\hline Semi-finished products of iron or plain steel & 0 & 72,2 \\
\hline Rods (other) of iron and plain steel & 0 & 97,9 \\
\hline Formed angle bars and special forms of iron or plain steel & 7,1 & 16,9 \\
\hline Flat mill products of other alloyed steels with min. width of $600 \mathrm{~mm}$ & 1,1 & 79,6 \\
\hline Rods (other) of other alloyed steels & 8,7 & 23,0 \\
\hline Pipes and hollow forms of ferrous (except iron cast) & 4,9 & 37,4 \\
\hline \multicolumn{3}{|l|}{ 1.2. Finished goods with high added value } \\
\hline New pneumatic rubber tires and covers & 73,0 & 0 \\
\hline Piston combustion engines & 32,9 & 12,3 \\
\hline Metal-cutting machines & 2,4 & 1,8 \\
\hline Electrical transformers, static electric converters & 19,1 & 0 \\
\hline Electrical batteries & 79,0 & 0 \\
\hline Light vehicles and other motor transport & 100 & 0 \\
\hline \multicolumn{3}{|l|}{ 2. Import } \\
\hline \multicolumn{3}{|c|}{ 2.1. Raw commodities and products with low added value } \\
\hline Onions, garlic and other bulbous vegetables & 62,0 & 37,7 \\
\hline Ferro-alloys & 23,9 & 0 \\
\hline Mill products of iron or plain steel with min. width of $600 \mathrm{~mm}$, plated & 91,3 & 0 \\
\hline Pipes and hollow forms of ferrous (except iron cast) & 84,3 & 3,6 \\
\hline Pipes and hollow forms (other) of ferrous & 53,4 & 41,7 \\
\hline \multicolumn{3}{|c|}{ 2.2. Finished goods with high added value } \\
\hline Machines and mechanisms for gathering, threshing of vestures & 0,3 & 99,7 \\
\hline Equipment for industrial preparing of food & 21,3 & 78,3 \\
\hline Metal-cutting machines & 2,7 & 72,9 \\
\hline Computing machines and their blocks, read-out equipment & 14,0 & 47,0 \\
\hline Ball and roll bearings & 10,1 & 46,7 \\
\hline Electrical motors and generators (except stationary electrical generators) & 27,4 & 40,8 \\
\hline Tractors & 0,3 & 97,0 \\
\hline Apparatuses and arrangement applied in medicine and veterinary medicine & 4,6 & 55,0 \\
\hline
\end{tabular}

* Kazakhstan isn't taken into account because of functioning of customs union.

ing out in the interest of European and American farmers. Besides that, the potential exists being still not used in this context, for instance, the absence of high-qualified meat from Mongolia on Russian market because of complicated customs procedures being profitable for basic competitors - suppliers of these products. Thus, organizing of external trade relations with SCO and BRIC(S) countries finally influences questions of economic safety in conformity with the level both of the country and of an individual through consumption of high qualified food-stuffs, what lowers, in its turn, the risk of arising of dangerous for health and life illnesses, of life duration shorting, and therefore of gross regional product decreasing.
2. International turnover of services. The hypothesis proposed by us in this sphere about increasing of role and importance of SCO and BRIC(S) for the economy of Sverdlovsk region is proving to be true still more. The leader among the country groups being considered is SCO, which value exceeded 2012 the turnover of EU countries (161,9 million dollar against 120,2), though yet for 11 years SCO ceded by this index more than twice for EU (5,3 million dollar against 11,6). The turnover of services with SCO countries increased during 2001-2012 more than in 30 times. The turnover with NAFTA countries has been remaining rather low (7,1 million dollar) (table 3). As for individual SCO countries, the biggest growth of export of services (more than twice) 2012 against 
Table 3

International turnover of services by Sverdlovsk region 2001-2012 [calculated on: 3]

\begin{tabular}{|l|c|c|c|}
\hline \multirow{2}{*}{} & \multicolumn{2}{|c|}{$\begin{array}{c}\text { Turnover of services, } \\
\text { million dollar }\end{array}$} & \multirow{2}{*}{$\begin{array}{c}\text { Basic growth, } \\
\text { times }\end{array}$} \\
\cline { 2 - 3 } & $\mathbf{2 0 0 1}$ & $\mathbf{2 0 1 2}$ & \\
\hline EU & 11,6 & 120,2 & 10,4 \\
\hline NAFTA & 16 & 7,1 & 0,4 \\
\hline BRIC(S) & 10,5 & 25,2 & 2,4 \\
\hline SCO & 5,3 & 161,9 & 30,5 \\
\hline
\end{tabular}

2011 was by Kyrgyzstan (from 5,8 million dollar to 12 million dollar), Uzbekistan (from 17,5 to 29,6 million dollar) and Tajikistan (from 43,4 to 50 million dollar) by the total growth of export of services of $11,5 \%$ (from 213,5 to 238,1 million dollar). These countries have also the biggest share at the total volume of export of services: Tajikistan (more than one fifth - $21 \%$ ), Uzbekistan (12,4 \%), Kyrgyzstan (5 \%), - so, the three of SCO countries accumulate almost $38,4 \%$ of export of services of the Sverdlovsk region.

3. Foreign investments. The indisputable leader concerning investing into the economy of Sverdlovsk region is EU. However, the foreign investors from SCO and BRIC(S) countries begin to contribute more means to the authorized capital of Sverdlovsk enterprises. Sverdlovsk region is attractive in the investment context thanks to its industrial and labor potential for China that is ready not only to supply finished goods into the region, but also to create enterprises. For example, a preliminary agreement was reached 2012 about building by China of a factory of household appliances on the territory of special economic zone "Titanium valley." Another one common business-plan of Middle Ural and China is the organization of production of innovative kinds of fuel elements. To launch assembly plants becomes for China increasingly profitable overseas because the work force in China is becoming gradually more expensive.

The enterprises - participants of IEI of Sverdlovsk region are legislators of the modernization proclaimed and related to basic priorities and of the innovative way of economic development of a region and country on the whole, are the participants of the long-term favorable projects "Development of defense industry complex of Russian Federation till 2020," "Development of an airplane industry for 2013-2025" and others, and also of major social projects of a region, which is the tool of effective planning of regional socio-economic development.

For instance, the mission of the scientific and production corporation "Dzerdzjinskiy
Uralvagonzavod" (carriage works) is the leadership in transport machinery on the basis of continuous innovations with the purpose including integration into the world economy. The corporation represents an integrated structure consisting of 30 companies - industrial plants, institutes for scientific research and development laboratories. There can be named among its foreign scientific and production associations Transmash (Krivoy Rog, Ukraine) and Guizhou Huition UVZ Casting Technology Co., Ltd. (Guizhou, China). This is in the sphere of sale UVZ International (Luxemburg), trade house "UVZ-Kazakhstan" (Astana, Kazakhstan), Baltic UVZ (Riga, Latvia), Sambre Et Meuse (Feignies, France) [15, p. 8, 12]. Constant countries - clients of UVZ are Cuba, Venezuela, Algeria, Belarus, Cyprus, Syria, Turkmenistan, Kazakhstan, China, Uganda, Yemen, Iran, India and Vietnam.

One unique enterprise of the region and an active participant of IEI is the joint stock company "Corporation VSMPO-AVISMA" (titanium production). The affiliate of the corporation was created May 2011, which offices and store-houses are located in Peking and the province Tientsin (China) being included into a free trade zone [18]. VSMPO-AVISMA also countersigned September 2012 memorandum about Russian-Indian cooperation with a state metallurgical company of India - Mishra Dhatu Nigam Limited (MIDHANI), and also with Indian-Russian scientific and technological centre (IRSTC) [19].

4. Migration between Sverdlovsk region and SCO and BRIC(S) countries. Almost four fifths $(79,4 \%)$ of the total volume of foreign labor migration falls in Sverdlovsk region to the share of foreign workers come from countries of Central Asia, where $44,6 \%$ are citizens of Tajikistan [13, p. 16]. At that men prevail among the arrived (67,8\% of total migrants amount), where $2 / 3$ are in the age of $18-29$ years, so in the prime of able-bodied age. $31,6 \%$ in the total structure of migrant's influx (not only of labor migrants, but of migrants on the whole) into Sverdlovsk region falls to Kyrgyzstan, 20,0 \% - to Tajikistan, 10,9 \% - to Kazakhstan, 5,5 \% - to Uzbekistan. The significant place among another SCO and BRIC(S) countries also belongs to China (the first place among non-CIS states): $7,1 \%$ falls to it [calculated on: 13 , p. 19]. Thus, the share of SCO and BRIC(S) countries in the structure of foreign migrants influx into Sverdlovsk region amounts to $75 \%$.

All this confirms the hypothesis proposed about increasing importance of SCO and BRIC(S) countries in international integration relations of Sverdlovsk region. 
Table 4

Correlations between indexes of international movement of goods and factors of production (IMGFP) and socioeconomic development of Sverdlovsk region

\begin{tabular}{|l|c|c|c|c|}
\hline \multirow{2}{*}{$\begin{array}{c}\text { Indexes of socio-economic } \\
\text { development of region }\end{array}$} & \multicolumn{3}{|c|}{ Indexes of IMGFP } \\
\cline { 2 - 5 } & $\begin{array}{c}\text { External trade } \\
\text { turnover }\end{array}$ & $\begin{array}{c}\text { Influx of foreign } \\
\text { investments }\end{array}$ & $\begin{array}{c}\text { Total external } \\
\text { migration }\end{array}$ & $\begin{array}{c}\text { Movement of } \\
\text { technologies }\end{array}$ \\
\hline Gross regional product & $0,76^{1}$ & 0,64 & 0,07 & 0,52 \\
\hline $\begin{array}{l}\text { Arrival of investments into } \\
\text { economy }\end{array}$ & 0,89 & $0,81^{2}$ & 0,16 & 0,68 \\
\hline Employment & 0,41 & 0,10 & $0,84^{3}$ & 0,49 \\
\hline Receipts into a budget & 0,88 & 0,72 & 0,22 & $0,79^{4}$ \\
\hline
\end{tabular}

Resource: calculated on data of Territorial branch of Federal service of state statistics in Sverdlovsk region.

Correlations reflecting the correlation coefficients highlighted are expressed as following equations (where $x$ are indexes of IMGFP, $Y$ - indexes of socio-economic development of region):

${ }^{1} Y=0,008467 x+3377,561$,

${ }^{2} Y=0,1231 x+4760,474$,

${ }^{3} Y=0,025 x+1935,8$,

${ }^{4} Y=0,058 x+115516$.

Analysis of correlation between indexes of an international movement of goods and factors of production (external trade turnover, influx of international investments, external migration, movement of technologies) and basic indexes of socio-economic development of Sverdlovsk region (gross regional product, investments, employment, receipts into a budget) showed the presence of high degree of correlation (table 4), which can be considered by working out of forecasts of socio-economic development of the region.

The discharging was foreseen on the next stage of the estimation - for socio-economic development of Sverdlovsk region for the period of 20112015 - of 22 target indexes that were united into 5 groups-clusters. The possibility was analyzed of significant influence (positive or negative) of each sphere of IEI displaying (that is of each sphere of displaying of the institutional component of IEI and of each kind of IMGFP) on the reaching of each index of socio-economic development. The list was formed on this basis of 101 indexes of influence that acts as a basis for defining of factors for SWOT-analysis - the finishing stage of the estimation, on which the analysis is carried out of exo- and endogenous factors of development of economic integration relations of Sverdlovsk region with SCO and BRIC(S) countries and the recommendations are proposed for development of these relations.

The list of factors for SWOT-analysis is composed on the basis of previous stages of estimation and immediately on the basis of indexes of influence of IEI on socio-economic development of Sverdlovsk region. Strengths of region are consisted in a presence of infrastructure necessary for IEI, in working out of technologies, in compati- bility of the regional economy with economies of SCO and BRIC(S) countries, etc. Weaknesses are investment risks, economic image of these countries in the region, etc.

The mention can be made - among a number of opportunities of the region - of the presence of its agreements about integration cooperation with SCO and BRIC(S) countries, of the presence of technologies etc.; among a number of threats of a raw export from the region, of labor migration from SCO countries, etc.

Combinations of groups of exo- and endogenous factors influencing the development of economic integration relations of Sverdlovsk region with representatives of SCO and BRIC(S) give four variants of strategies of region's participation at the IEI processes (strategies of development of mainly: external trade potential; innovative potential; investment potential; socio-labor potential of a region).

These strategies presuppose a use of strengths of region and opportunities of economic relations within SCO and BRIC(S) with the purpose of compensation of weaknesses and threats. Therefore, the realization of those strategies will be less expensive (and faster) for the region that presuppose a use of positive factors.

The recommendations are worked out on the basis of this analysis for each strategy accordingly to its direction, reflecting author's typology of spheres of IEI displaying. The mention can be made - among recommendations for realization of strategy of external trade potential development of Sverdlovsk region - of following: active use of geographic location and infrastructure opportunities of region for participation at international transport corridors, including organization 
in the region of universal transport-logistic hub in particular for transit of goods between EU, Central Asia and Pacific Rim; creating of international congress and exhibition centre of corresponding level and of joint information portal for actual and potential participants of IEI of the region; establishing of effective change of necessary information with target regions - participants of IEI; more active use of different international measures both in the region and with its participation overseas for creation of corresponding image of the region (exhibitions of products of regional enterprises of high degree of processing, congresses, symposiums), application of tools of territory branding etc. Strategy of innovative potential development includes export of technologies into Central Asian countries of SCO, Brazil, South Africa, etc. The realization of strategy of investment potential development presupposes a more purposeful use of opportunities of such famous tool as improving business dealing conditions and increasing of regional investment attractiveness. It's necessary for the realization of strategy of socio-labor potential development the more purposeful use of results of monitoring of regional labor market, with the aim to reveal the branches where a use of migrants is promising, and carrying out of their education, advanced training and essential certification within a centre for preparing of specialists for SCO and BRIC(S) countries, and also the creation of centers of different cultures.

\section{Basic conclusions}

Thus, the tendencies are clearly appeared in the world economy in previous decades of slowing down of development dynamics and of share of the developed countries and of increasing - of the developing, - what leads to a change of correlation between world economic centre and world economic periphery. It determined to a large extent a forming of integration processes of the new type, for instance, within SCO and BRIC(S), having distinctive lines and peculiarities against traditional integration unions (EU, NAFTA).

International movement of goods and factors of production with representatives of integration associations of a new type (SCO and BRIC(S)) is very important for the economy of Sverdlovsk region. The export of the region into these country groups has a higher degree of processing than the export into traditional economic integration unions EU and NAFTA formed by developed countries. Certain countries of SCO are the 100-percent importers of finished goods with a high degree of processing (so, $100 \%$ of light vehicles and another motor transport was exported 2012 into Tajikistan); penetration into markets of namely these countries gives to Russia and its regions a chance to change a raw orientation of export. SCO and BRIC(S) countries play an important role in import of food products into Sverdlovsk region, among which there're those that aren't being produced in the region or produced in not sufficient amounts. SCO members (especially, Central Asian countries) are active donors of labor migrants into Sverdlovsk region (from Central Asia comes $3 / 4$ of foreign labor migrants), what requires a rise of attention to the questions of migration policy.

This all confirms the increasing importance of international cooperation of the region with country groups SCO and BRIC(S) both in quantitative and in qualitative relation. Active penetrating into the markets of these countries and establishing of all-round economic integration with them can change by cardinal way a direction of flows of science-intensive and high-technological goods and services, capital and technologies. If nowadays basic flows of these goods and factors of production enter from developed countries, in the way of expanding of economic cooperation within SCO and BRIC(S) Sverdlovsk region in particular and Russia on the whole get opportunity to become selves a source of goods and services of high degree of processing and capital investing. Thus, a purposeful considering of the tendency of forming of integration processes of the new type in the interest of regional socio-economic development allows Sverdlovsk region to get additional benefits of both quantitative and qualitative character from active use of its potential of economic cooperation.

\section{References}

1. Fituni, L. L. \& Abramova, I. O. (2012). Zakonomernosti formirovaniya i smeny modeley mirovogo ekonomicheskogo razvitiya [Regularities of forming and change of models of world economic development]. Mirovaya ekonomika i mezhdunarodnyye otnosheniya [World economy and international economic relations], 7, 3-15.

2. Frolova, Ye. D. \& Klyuev, Yu. B. (2013). Konkurentnosposobnost Rossii v kontekste geoekonomicheskogo podkhodov [Competitiveness of Russia in the context of traditional and geo-economic approaches]. Bezopasnost Evrazii [Safety of Eurasia], 2(46), 225.

3. Golovina, A. S. \& Radkovskaya, Ye. V. (2010). Razrabotka sistemy amaliza ekonomicheskoy statistiki dlya regionalnykh issledovaniy [Working out of the system of analysis of economic statistics for regional research]. Nauchnyye trudy Volnogo ekonomicheskogo obshchestva Rossii [Scientific proceedings of the Free economic community Russia], Vol. 143, 294-300. 
4. Kuklin, A. A., Cherepanova, A. V. \& Nekrasova, Ye. V. (2009). Sotsialno-demograficheskaya bezopasnost regionov Rossii: problemy diagnostiki i prognozirovaniya [Socio-demographic security of the Russian regions: problems of diagnostics and prognostication]. Narodonaseleniye [Population], 2, 121-133.

5. Kuklin, A. A., Cherepanova, A. V. \& Tarasyev, A. A. (2012). Modeliravonaie potokov trudovykh migrantov v region (na primere Sverdlovskoy oblasti) [Modelling of flows of labor migrants into region (on the example of Sverdlovsk region)]. Uroven zhizni naseleniya regionov Rossii [Level of life of the population of regions of Russia], 3, 79-86.

6. Maltsev, A. A. (2009). Vedushchie eksportyory uralskoy promyshlennosti: territorialno-otraslevoy razrez [Leading exporters of Ural industry: territorial and branch structure]. Izvestiya Uralskogo gosudarstvennogo ekonomicheskogo universiteta [Bulletin of Ural state university of economics], Vol. 24, 2, 1125-137.

7. Kuzmin, A. I, Nosov, A. A, Davidenko, A. N. \& Ilinbayeva, Ye. A. (2013). Opyt teoreticheskogo i empiricheskogo issledovaniya mayatnikovoy trudovoy migratsii $\mathrm{v}$ regionakh Rossii [Experience of theoretical and empirical research of commuting in Russian regions]. Zhurnal ekonomicheskoy teorii [Journal of economic theory], 3, 259-264.

8. Migratsiya naseleniya Sverdlovskoy oblasti v 2012 godu: statisticheskiy sbornik. Territorialnyy organ Federalnoy zluzhby gosudarstvennnoy statistiki po Sverdlovskoy oblasti [Migration of population of Sverdlovsk region 2012: statistical collection. Territorial branch of Federal service of state statistics in Sverdlovsk region]. Yekaterinburg, 48.

9. Mirovyye zapasy prirodnogo gaza [World reserves of natural gas]. Prirodnyy gaz — proekt Aleksandra Dolgikh [Natural gas — project of A. Dolgikh]. Available at: http://dolgikh.com/index/0-39 [доступ: 18.5.2013]; Situatsiya na mirovom rynke zheleznoy rudy [Situation on the world market of iron ore]. Metallurgicheskiy byulleten [Metallurgical bulletin]. Available at: http://www. metalbulletin.ru/publications/3860/ [доступ: 18.5.2013]; World factbook: Guide to country comparisons // Central Intelligence Office. Available athttps://www.cia.gov/library/publications/the-world-factbook/rankorder/rankorderguide.html (date of access: 15.5.2013).

10. My dolzhny vsyo vremya zaglyadyvat v zaavtrashniy den [We should always look into tomorrow]. Prime. 27.11.2012 Available at: http://www.1prime.ru/Interview/20121127/757646243.html (date of access: 3.4.2014].

11. Nauchno-proizvodstvennaya korporatsiya «Uralvagonzavod» [Scientific and production corporation "Uralvagonzavod"] (2013). Booklet, 23. Available at: http://www.uvz.ru/export/UVZ_Booklet_WEB_Rus.pdf (date of access: 2.4.2014).

12. Patrusheva, Ye. G., Konovalova, G. G. \& Sapir, Ye. V. (2012). K voprosu otsenki sotsialno-ekonomicheskogo razvitiya regiona [On the issue of assessment of socio-economic regional development]. Vestnik Yaroslavskogo gosudarstvennogo universiteta im. P.G. Demidova. Seriya Gumanitarnyye nauki [Bulletin of Yaroslavl state university in the name of P. G. Demidov. Sery of humanities], 1 , 149-154.

13. Ratner, A. V. \& Andreyeva, Ye. L. (2011). Shankhayskaya organizatsiya sotrudnichestva: opyt mezhdistsiplinarnogo issledovaniya [The Shanghai cooperation organization: An experience of interdisciplinary research]. Prostranstvennaya ekonomika [Spatial economics], 2, 182-183.

14. Tatarkin, A. I., Andreyeva, Ye. L. \& Ranter A. V. (2014). Imperativy sovremennogo ekonomicheskogo razvitiya: mirovyye trendy i rossiyskaya realnost [Imperatives of current economic development: world trends and Russian reality]. Voprosy ekonomiki [Questions of economics], 5.

15. Vneshneekonomicheskaya deyatelnost Sverdlovskoy oblasti v 2001, 2003, 2012 gg.; Vneshnyaya torgovlya Sverdlovskoy oblasti $v$ 2003-2012 gg.: stat. byulleteni [External economic activity of Sverdlovsk region 2001, 2003, 2012; Foreign trade of Sverdlovsk region 2003-2012: statistical bulletins]. (2002-2013). Terriotorialnye organ Federalnoy sluzhby gosudarstvennoy statistiki po Sverdlovskoy oblasti [Territorial branch of Federal service of state statistics in Sverdlovsk region]. Yekaterinuburg.

16. VSMPO-AVISMA gotovo k postavkam titana docherney kompanii $\mathrm{v}$ Kitaye [VSMPO-AVISMA is ready to delivery titanium to its affiliate in China]. RusBusiness news. 19.10.2011 Available at: http://www.rusbiznews.ru/news/n1156.html [date of access: 3.4.2014].

17. Atale, N. (2012). A decade of BRICs: prospects and challenges for the next decade. The Indian journal of management, 5, 2, 16-21.

18. Golejewska, A. (2013). Input-output analysis of regional innovativeness. The casse of the Visegrad group. Journal of legal and economic issues of Central Europe, 4 (2).

19. König, J. \& Ohr, R. (2013). Different Efforts in European Economic Integration: Implications of the EU Index. Journal of common market studies, 51, 6, 1074-1090.

20. Stuenkel, O. (2013). The financial crisis, contested legitimacy, and the genesis of intra-BRICS cooperation. Global governance, 19, 4, 611-630.

\section{Information about the authors}

Andreyeva Yelena Leonidovna (Yekaterinburg, Russia) - Doctor of Economics, Professor, Head of the Centre of Regional Comparative Research, the Institute of Economics of the Ural Branch of the Russian Academy of Sciences (29, Moskovskaya st., Yekaterinburg, 620014, Russia, e-mail: elenandr@mail.ru).

Zakharova Viktoriya Vladimirovna (Yekaterinburg, Russia) - Leading Specialist of Department for External Relations, Presidium of the Ural Branch of the Russian Academy of Sciences; PhD Student, the Institute of Economics of the Ural Branch of the Russian Academy of Sciences (91, Pervomayskaya st., Yekaterinburg, 620990, Russia, e-mail: zakharovavika@gmail.com).

Ratner Artyom Vitalyevich (Yekaterinburg, Russia) - PhD in Economics, Research Assistant, the Institute of Economics of the Ural Branch of the Russian Academy of Sciences (29, Moskovskaya st., Yekaterinburg, 620014, Russia, e-mail: aratner@inbox. $\mathrm{ru}$ ). 